\title{
Urinary Pathogens and Their Antimicrobial Susceptibility in Patients with Indwelling Urinary Catheter
}

\section{Onipede Anthony ${ }^{1,2}$, Oyekale T Oluwalana ${ }^{1}$, Olopade Bolatito ${ }^{1}$, Olaniran Olaniran ${ }^{1}$, Oyelese Adesola ${ }^{1,2}$ and Ogunniyi Titus A $^{2}$}

\author{
${ }^{1}$ Department of Medical Microbiology and Parasitology, Obafemi Awolowo University Teaching Hospital, \\ ${ }^{2}$ Obafemi Awolowo University lle-Ife, Osun State, Nigeria
}

\begin{abstract}
The indwelling urinary catheter (IUC) is the most significant risk factor for developing nosocomial urinary tract infections (UTIs). In order to determine the spectrum of bacterial etiology and antibiotic resistance pattern of uropathogens causing catheter associated UTI, a convenient sample size of ninety-two (92) patients on urethral catheter was investigated. Ethical approval for the study was obtained from the OAUTHC research and ethical committee. Catheter stream urine samples were obtained from all patients and cultured on appropriate culture media. Suspected isolates were identified by a combination of standard tests and using MICROBACT GNA12A/B/E. Susceptibility of the isolates against thirteen (13) antibiotics was performed by the disc diffusion method. Significant bacteriuria was observed in $60.9 \%$ (56) catheter specimen urine (CSU) received, while $39.1 \%$ (36) were culture negative. Of the 56 positive culture, the predominant organisms were Klebsiella oxytoca, $28.6 \%(16)$, Proteus vulgaris, $23.2 \%$ (13) and Staphylococcus aureus, $12.5 \%$ (7). Overall, the antimicrobial susceptibility results showed that all the isolates were highly resistant to the antibiotics tested. Over $50 \%$ resistance was recorded for trimethoprim/sulfamethoxazole, gentamicin and amoxicillin/clavulanic acid. More than $25 \%$ of the isolates were resistant to nitrofurantoin. This study indicates that catheter stream UTI caused by multiply resistant bacteria are common in our hospital. There is a need to establish standard guidelines on the care of catheter for all units in the hospital with a view to preventing nosocomial infections associated with the use of the catheter in patients. We also advocated prudent use of antibiotics.
\end{abstract}

\section{Key words: Antibiotic resistance, Urinary catheter, Uropathogens, Urinary tract infection}

Received 27 March 2010/ Accepted 1 June 2010

\section{INTRODUCTION}

Urinary tract infections (UTIs) are the most common infections found in the hospital as well as long-term care setting. The indwelling urinary catheter (IUC) is the most significant risk factor for developing catheter-associated urinary tract infections (CAUTIs). The risk of acquiring a urinary tract infection depends on the method and duration of catheterisation, the quality of catheter care, and host susceptibility among others. Several studies have indicated that between 75 and $80 \%$ of all healthcare associated UTIs follow the insertion of a urinary catheter (Bryan and
Reynolds 1984; Bonadio et al., 2001). Although usually benign, CAUTI causes bacteremia in 2$4 \%$ of patients and have been associated with a case fatality rate three times as high as nonbacteriuric patients (Barkham et al., 1996; Tal et al., 2005).

Catheter-associated urinary tract infections are associated with increased morbidity, mortality, and costs resulting from additional diagnostic testing, change of treatment regimes and increased length of stay in the hospital (Bryan and Reynolds, 1984; Askarian et al., 2003). 
Although not all CAUTIs can be prevented, it is believed that the incidence can be reduced through active surveillance and by the proper management of the indwelling catheter (Apisarnthanarak et al., 2007). Therefore, this study was designed to determine the spectrum of bacterial etiology and antibiotic resistance pattern of uropathogens in catheter associated UTI and to provide local epidemiological data on CAUTI in our hospital in support of the activities of the Infection Control Unit.

\section{MATERIALS AND METHODS}

\section{Study Setting and Design}

The study was conducted at Obafemi Awolowo University Teaching Hospital, lle-lfe, Southwestern, Nigeria between October 2007 and March 2008. A convenient sample size of ninetytwo (92) patients on urethral catheter was included in the study. Ethical approval for the study was obtained from the OAUTHC Research and Ethical Committee. A specially designed surveillance form which required the primary physician attending to the patient to fill in the details was employed for the study. Where it was not possible, information on the patient was extracted from the case notes. The surveillance form was approximately used to determine the number of days for the onset of bacteriuria based on the following information: date of hospital admission, date of catheter insertion, reason, infection onset and specimen collection. In accordance with the study protocol, patients were monitored from the day the urinary catheter was inserted until a CAUTI was diagnosed, the patient was discharged, transferred or died, or until the 30 day surveillance period ends. Admission data (number of admissions and number of patient days) for each ward was also noted. A worksheet was designed for recording the results of all laboratory tests. Results of the microscopy and all positive cultures for any pathogens were reported immediately to the attending physician and or the Infection Control Unit.

\section{Microbiological Tests}

There was no serial catheter urine culture but catheter stream urine was collected from all patients suspected with CAUTI and on closed catheter drainage. Detailed specimen collection, procedure and transportation were based WHO guidelines (Lau et al., 2007; Long and Vince, 2007). Using, the calibrated loop $(1 \mu \mathrm{l})$ technique for semi-quantitative urine culture, the samples were cultured using CLED agar (Oxoid, UK). Plates were incubated aerobically overnight at $37^{\circ} \mathrm{C}$. Those with significant growth were identified by standard bacteriological methods including colony morphology, Gram stain, catalase, coagulase test and the use of MICROBACT 12E (MB1130 - OXOID, UK) for Gram negative bacilli. Antibiotic sensitivity pattern of the bacterial isolates were determined by agar diffusion method and interpreted according to published guidelines (Rosenblatt, 1983; Chaitram et al., 2003).

\section{Data Analysis}

Analysis of all clinical and laboratory data was carried out using the SPSS. Parameters were compared using univariate and multivariate logistic regression and chi-square tests. Student ttest was used to compare the outcome of UTI due to catheterization. Categorical data was expressed as mean \pm SD and a $p$-value of $<0.05$ was accepted as being statistically significant.

\section{RESULTS}

A total of ninety-two (92) patients on urinary catheter were surveyed in this study. There were $52(56.5 \%)$ females with a culture positive rate of $70.6 \%(36)$ and $40(43.5 \%)$ males with a culture positive rate of $78 \%$. The mean age was 40.8 years (SD 19.6years). The distribution of the catheterized patients according to wards is as follows: post natal ward: 22(23.9\%), gynaecological ward: $4(4.3 \%)$ and female medical ward: $14(15.2 \%)$ and male medical ward: $14(15.2 \%)$. In the adult surgical wards, there were $12(13 \%)$ females and 14 (15.2) males, while pediatrics surgery was $6(6.5 \%)$ males. The subspecialty wards like the Intensive Care Unit (ICU), Orthopedics, and Renal wards had 2 (2.2\%) males each. The primary unit where catheter was inserted could not ascertained for fifty-two patients $\{52(56.5 \%)\}$. In 40 patients for whom the point of insertion of catheter could be ascertained $33.7 \%$ (Operating Theater $12(13 \%)$ and wards $19(20.7 \%))$ had catheter insertion between the theater and the wards while Accident and Emergency unit was 9(9.8\%).

The average number of days for the onset of bacteriuria after catherisation was 12.2 days (range day 2- 60 days) in twenty-one (21) patients. It was difficult to determine exactly the onset of bacteriuria for seventy-one 
(71) and duration of catheter placement in fortyone (41) patients, which on the average was 7 days (range 1-90days \pm 17 ) could not be determined since the data were missing from their record. Significant bacteriuria $\left(10^{5}\right.$ colony forming unit $/ \mathrm{ml}$ ) was observed in $60.9 \%$ (56) of catheter specimen urine (CSU) received while $39.1 \% 36$ did not have a significant growth.

\section{Table 1: Distribution of Bacterial isolates from Culture Positive Specimens}

\begin{tabular}{|l|l|}
\hline Bacterial Organisms & $\begin{array}{l}\text { Frequency (\%) of } \\
\text { Isolation }\end{array}$ \\
\hline Acinetobacter iwoffi & $2(3.6)$. \\
Citrobacter freundi & $2(3.6)$ \\
Escherichia coli & $3(5.4)$ \\
Enterobacter agglomerans & $3(5.4)$ \\
Klebsiella oxytoca & $16(28.6)$ \\
Klebsiella pneumoniae & $4(7.1)$ \\
Proteus vulgaris & $13(23.2)$ \\
Providencial spp & $1(1.8)$ \\
Pseudomonas aeruginosa & $2(3.6)$ \\
Serratia marcescens & $2(3.6)$ \\
Staphylococcus aureus & $7(12.5)$ \\
Yersinia enterocolitica & $1(1.8)$
\end{tabular}

Of the 56 specimens with significant growths, $87.5 \%$ (49) was due to a variety of gram-negative organisms while $12.5 \%$ (7) was attributed to Staphylococcus aureus alone. Amongst the gramnegative organisms, isolates from the genera, Klebsiella, 35.7\% (20) and Proteus, 23.2\% (13) were predominant, followed by Escherichia and Enterobacter that were $5.4 \%$ (3) each. Other genera such as Acinetobacter, Citrobacter, Serratia and Pseudomonas were $3.6 \%$ (2) each. Providencia and Yersinia had the least isolation rate (Table 2).

Taking an overall view of the antimicrobial susceptibility results of the isolates, they were highly resistant to the tested antibiotics. The resistance rate ranges from $50-100 \%$ for trimethoprim/sulfamethoxazole, nalidixic acid and amoxicillin/clavulanic acid. Over $75 \%$ of the isolates were resistant to gentamicin and more than $25 \%$ to nitrofurantoin. Proteus vulgaris had low resistance to ceftriaxone (15.4\%) whereas $\mathrm{E}$. coli was resistant across the different classes of antibiotics. Table 3 shows the specific susceptibility profile of each isolate to the antimicrobial tested.

\section{DISCUSSION}

Hospital-acquired catheter-associated urinary tract infection (CAUTI) is one of the major conditions of nosocomial infections in the health care setting. Our findings indicate that this can be a major problem also in our health care setting considering that $60 \%$ of patients on catheter had significant bacteriuria. The high percentage of significant bacteriuria recorded is consistent with similar observations elsewhere (Bonadio et al., 2001; Bonadio et al., 2005). Although, in this study, the culture positive rate reported is higher than $51 \%$ reported from South Africa (Habte et al., 2009), 43.3\% from Ethiopia (Teshager et al., 2008), 30\% from Nicaragua (Matute et al., 2004) and $39 \%$ from India (Kothari and Sagar, 2008), it was lower than the $88.5 \%$ culture positive rate reported in a study carried out within the same geographic environment as our hospital (Taiwo and Aderounmu, 2006). This can be explained by the differences in the population studied such as mean age, pre-morbid state and the reasons for admission.

However, evidence-based guidelines indicate that asymptomatic bacteriuria is not a clinically significant condition that warrant treatment intervention (Cope et al., 2009). This is particularly of significant interest in developing country where hospital acquired infection programs need optimum strengthening to reduce the incidence of catheter-associated UTI (Onipede et al., 2004) and to avoid unwarranted treatment of asymptomatic bacteriuria. In support of this point of view, this study observed that several key information that are essential to infection control activities were not documented. Information such as point and date of insertion of catheter, as well as the duration of catheter insertion which are important to determine the evolution (i.e. where and onset) of bacteriuria were missing in the hospital records of most of the patients.

Nevertheless, there was strong indication of symptomatic bacteriuria which warranted specimen collection except in a few. For cases that were not obviously symptomatic, additional information would have justified the need to commence antibiotics together with other interventions such as catheter change. This is contrary to Cope and colleagues' recommendation that better recognition of asymptomatic bacteriuria from symptomatic CAUTI, which are consistent with evidence-based guidelines, may play an important role in reducing unneeded antibiotic usage in hospitalized patients (Cope et al., 2009). 
Furthermore, the institution of a CAUTI prevention program which include staff education, ongoing monitoring of CAUTI incidence, monitoring catheter insertion and ensuring prompt removal, and careful attention to techniques for catheterization and catheter care has been advocated for developing countries (Willson et al., 2009). Therefore, the need to review of the existing policy and guidelines on the insertion and care of urinary catheter in our health care settings is indispensable.

The pattern of uropathogens cultured in this study is consistent with similar findings elsewhere in patients with CAUTI in South Africa (Habte et al., 2009), Kuwait (Al-sweih et al., 2005), Nigeria (Iregbu et al., 2002) and Iran (Askarian et al., 2003), in which Gram-negative bacilli, especially members of the family enterobacteriacae were the predominant isolates. However, in this study, members of the genus Klebsiella $35.7 \%$ were more commonly identified compared to $E$. coli $5.4 \%$, an observation that has been documented in CAUTI elsewhere (Habte et al., 2009). Other researchers have also concluded that the frequency of isolation of $E$. coli as a causative agent of UTI is slowly declining and it is being replaced by other members of the enterobacteriaceae and enterococci (Ko et al., 2008; Teshager et al., 2008).

Overall, the antimicrobial susceptibility results showed that all the isolates were multiply resistant to the tested antibiotics. This high-level resistance to commonly used antimicrobial drugs by uropathogens has been documented
(Anandkumar et al., 2003) and it is consistent with our findings. There are many factors that may be responsible for the high level of resistance such as the frequent use of antibiotics for therapy and prophylaxis, the ease of procurement of antibiotics in developing country and other socioeconomic factors as documented by Okeke et al. (1999). Although extended spectrum betalactamase (ESBL) in uropathogens has been documented (Kothari and Sagar, 2008), in this study, there was no deliberate attempts to test for extended spectrum beta lactamase (ESBL) in the isolates and this is a limitation but one can safely assume that they are present judging by the high level of resistance across different classes of antibiotics. More research is clearly necessary to ascertain this form of resistance among uropathogens in this setting.

In conclusion, this study indicates that catheter stream UTI caused by multiply resistant Gramnegative bacteria is common in our hospital. Regular surveillance of the bacterial spectrum and their susceptibility patterns to various antimicrobial agents are therefore essential for a rational use of antimicrobial drugs. Also, there is a need to establish standard guidelines on the care of catheter for all units in the hospital with a view to preventing nosocomial infections associated with the device in patients.

\section{ACKNOWLEDGEMENTS}

The authors thank all the contributors to this study, particularly the hospital and university staff for their support. 
Table 2: Antimicrobial Resistant Pattern of Isolates

\begin{tabular}{|c|c|c|c|c|c|c|c|c|c|c|c|c|c|}
\hline 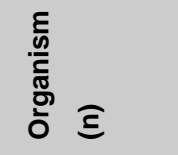 & 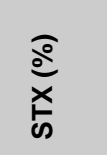 & $\begin{array}{l}\text { ळ } \\
\bar{E}\end{array}$ &  & $\frac{\frac{0}{3}}{\frac{1}{2}}$ & $\begin{array}{l}\frac{0}{\varrho} \\
\stackrel{x}{\alpha}\end{array}$ & $\frac{\widehat{o}}{\stackrel{1}{0}}$ &  & $\frac{\mathfrak{o}}{\frac{1}{5}}$ & $\frac{\overparen{\varrho}}{\stackrel{5}{⺊}}$ & $\frac{\widehat{o}}{\stackrel{x}{a}}$ & 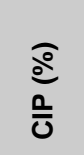 & $\begin{array}{l}\text { @ } \\
\text { ठํ }\end{array}$ & $\frac{\overparen{\circ}}{\stackrel{0}{\frac{c}{5}}}$ \\
\hline $\begin{array}{l}\text { A. iwoffi } \\
\text { (2) }\end{array}$ & $1(50)$ & $1(50)$ & $\begin{array}{l}2 \\
(100)\end{array}$ & $\begin{array}{l}2 \\
(100)\end{array}$ & NT & $1(50)$ & $1(50)$ & NT & NT & $1(50)$ & NT & NT & NT \\
\hline C. freundi (2) & $2(100)$ & $1(50)$ & $2(100)$ & $1(50)$ & NT & $1(50)$ & NT & NT & NT & NT & NT & $\begin{array}{l}1 \\
(50)\end{array}$ & $\begin{array}{l}1 \\
(50)\end{array}$ \\
\hline $\begin{array}{l}\text { E. coli } \\
\text { (3) }\end{array}$ & $3(100)$ & $\begin{array}{l}3 \\
(100)\end{array}$ & $\begin{array}{l}3 \\
(100)\end{array}$ & $\begin{array}{l}3 \\
(100)\end{array}$ & NT & $\begin{array}{l}3 \\
(100)\end{array}$ & $\begin{array}{l}3 \\
(100)\end{array}$ & $\begin{array}{l}3 \\
(100)\end{array}$ & $\begin{array}{l}3 \\
(100)\end{array}$ & $\begin{array}{l}3 \\
(100)\end{array}$ & NT & NT & NT \\
\hline $\begin{array}{l}\text { E. } \\
\text { agglomerans } \\
\text { (3) }\end{array}$ & $3(100)$ & $2(66)$ & $3(100)$ & $3(100)$ & NT & $\begin{array}{l}3 \\
(100)\end{array}$ & $\begin{array}{l}3 \\
(100)\end{array}$ & NT & NT & $\begin{array}{l}3 \\
(100)\end{array}$ & NT & NT & NT \\
\hline $\begin{array}{l}\text { K. oxytoca } \\
\text { (16) }\end{array}$ & $15(94)$ & 7(44) & $14(88)$ & $14(88)$ & & $\begin{array}{l}10 \\
(71)\end{array}$ & $\begin{array}{l}11 \\
(79)\end{array}$ & & NT & $\begin{array}{l}13 \\
(81)\end{array}$ & NT & NT & NT \\
\hline $\begin{array}{l}\text { K. } \\
\text { pneumoniae } \\
\text { (4) }\end{array}$ & $4(100)$ & 1(25) & $3(75)$ & $4(100)$ & $2(50)$ & $\begin{array}{l}4 \\
(100)\end{array}$ & $3(75)$ & NT & NT & $2(50)$ & NT & $\begin{array}{l}2 \\
(50)\end{array}$ & $\begin{array}{l}2 \\
(50)\end{array}$ \\
\hline $\begin{array}{l}\text { P. vulgaris } \\
\text { (13) }\end{array}$ & 11(85) & $8(61)$ & $\begin{array}{l}12 \\
(92)\end{array}$ & $8(61)$ & $2(15)$ & $\begin{array}{l}9 \\
(69)\end{array}$ & $\begin{array}{l}11 \\
(85)\end{array}$ & $1(8)$ & NT & $\begin{array}{l}11 \\
(85)\end{array}$ & NT & NT & NT \\
\hline $\begin{array}{l}\text { Providencia } \\
\text { spp (1) }\end{array}$ & $1(100)$ & $\begin{array}{l}1 \\
(100)\end{array}$ & $\begin{array}{l}1 \\
(100)\end{array}$ & $\begin{array}{l}1 \\
(100)\end{array}$ & $\begin{array}{l}1 \\
(100)\end{array}$ & $\begin{array}{l}1 \\
(100)\end{array}$ & $\begin{array}{l}1 \\
(100)\end{array}$ & NT & NT & $\begin{array}{l}1 \\
(100)\end{array}$ & NT & NT & NT \\
\hline $\begin{array}{l}P \text {. } \\
\text { aeruginosa } \\
\text { (2) }\end{array}$ & $2(100)$ & NT & $\begin{array}{l}2 \\
(100)\end{array}$ & $1(50)$ & NT & $1(50)$ & $2(100)$ & $2(100)$ & $2(100)$ & $\begin{array}{l}2 \\
(100)\end{array}$ & $\begin{array}{l}2 \\
(100)\end{array}$ & NT & NT \\
\hline $\begin{array}{l}\text { S. } \\
\text { marcescens } \\
\text { (2) }\end{array}$ & $2(100)$ & NT & $\begin{array}{l}2 \\
(100)\end{array}$ & $\begin{array}{l}2 \\
(100)\end{array}$ & NT & $\begin{array}{l}2 \\
(100)\end{array}$ & $1(50)$ & NT & NT & $2(100)$ & NT & NT & NT \\
\hline $\begin{array}{l}\text { S. aureus } \\
\text { (7) }\end{array}$ & 7(100) & NT & $6(86)$ & NT & $5(71)$ & $3(43)$ & $\begin{array}{l}7 \\
(100)\end{array}$ & $3(43)$ & $3(43)$ & $\begin{array}{l}7 \\
(100)\end{array}$ & $3(43)$ & NT & NT \\
\hline $\begin{array}{l}Y \text {. } \\
\text { enterocolitica } \\
\text { (1) }\end{array}$ & $1(100)$ & NT & $1(100)$ & $\begin{array}{l}1 \\
(100)\end{array}$ & NT & $\begin{array}{l}1 \\
(100)\end{array}$ & $\begin{array}{l}1 \\
(100)\end{array}$ & NT & NT & $\begin{array}{l}1 \\
(100)\end{array}$ & NT & NT & NT \\
\hline
\end{tabular}

Legend: *Figures in parenthesis show number of isolates tested. NT=Not tested. STX= Trimethoprim/Sulfamethoxazole, NIT= Nitrofurantoin, GEN = Gentamicin , NAL= nalidixic Acid, AXO= Ceftriaxone OFX = Ofloxacin, AUG= Amoxicillin/Clavulanic acid, $\mathrm{CHL}=$ Chloramphenicol , TET = Tetracycline, AMX=Amoxicillin, ERY = Erythromycin, CIP= Ciprofloxacin , COL=Colistin, STR= Streptomycin, AMP = Ampicillin

\section{REFERENCES}

Al-Sweih N, Jamal W and Rotimi VO (2005). Spectrum and Antibiotic Resistance of Uropathogens Isolated from Hospital and
Community Patients with Urinary Tract Infections in Two Large Hospitals in Kuwait. Med Princ Pract. 14: 401-407. 
Anandkumar H, Kapur I and Dayanand A (2003). Increasing Prevalence of Antibiotic Resistance and Multi -drug Resistance Among Uropathogens. J Commun Dis. 35: 102-8.

Apisarnthanarak A, Thongphubeth K, Sirinvaravong S, Kitkangvan D, Yuekyen C, Warachan B, Warren DK and Fraser VJ (2007). Effectiveness of Multifaceted Hospital-wide Quality Improvement Programs Featuring an Intervention to Remove Unnecessary Urinary Catheters at a Tertiary Care Center in Thailand. Infect Control Hosp Epidemiol. 28: 791-8.

Askarian $M$, Hosseini RS, Kheirandish $P$ and Memish ZA (2003). Incidence of Urinary Tract and Bloodstream Infections in Ghotbeddin Burn Center, Shiraz 2000-2001. Burns. 29: 455-9.

Barkham TM, Martin FC and Eykyn SJ (1996). Delay in the Diagnosis of Bacteraemic Urinary Tract Infection in Elderly Patients. Age Ageing. 25: 130-2.

Bonadio $M$, Meini $M$, Spitaleri $P$ and Gigli $C$ (2001). Current Microbiological and Clinical Aspects of Urinary Tract Infections. Eur Urol. 40: 439-44.

Bonadio M, Pichierri G, Costarelli S, Morelli G, Tanzilli P, Tartaglia $T$ and Mori S (2005). Catheter-associated Urinary Tract Infections (CAUTI): Distribution of Uropathogens and Patterns of Antimicrobial Resistance in an Italian Hospital (1996-2003). J Chemother. 17: 560-2.

Bryan CS and Reynolds KL (1984). Hospitalacquired Bacteremic Urinary Tract Infection: Epidemiology and Outcome. J Urol. 132: 494-8.

Chaitram JM, Jevitt LA, Lary S and Tenover FC (2003). The World Health Organization's External Quality Assurance System Proficiency Testing Program Has Improved the Accuracy of Antimicrobial Susceptibility Testing and Reporting Among Participating Laboratories Using NCCLS Methods. J Clin Microbiol 41: 2372-7.

Cope M, Cevallos ME, Cadle RM, Darouiche RO, Musher DM, Trautner BW (2009). Inappropriate Treatment of Catheter-associated Asymptomatic Bacteriuria in a Tertiary Care Hospital. Clin Infect Dis. 48: 1182-8.
Habte TM, Dube S, Ismail $\mathrm{N}$ and Hoosen AA (2009). Hospital and Community Isolates of Uropathogens at A Tertiary Hospital in South Africa. S Afr Med J. 99: 584-7.

Iregbu KC, Ogunsola FT and Odugbemi TO (2002). Infections Caused by Acinetobacter Species And Their Susceptibility to 14 Antibiotics in Lagos University Teaching Hospital, Lagos. West Afr J Med. 21: 226-9.

Ko MC, Liu CK, Woung LC, Lee WK, Jeng HS, Lu $\mathrm{SH}$, Chiang HS and Li CY (2008). Species and Antimicrobial Resistance of Uropathogens Isolated from Patients with Urinary Catheter. Tohoku J Exp Med. 214 : 311-9.

Kothari A and Sagar V (2008). Antibiotic Resistance in Pathogens Causing Communityacquired Urinary Tract Infections in India: A Multicenter Study. J Infect Dev Ctries. 2: 354-8.

Lau AY, Wong SN, Yip KT, Fong KW, Li SP, and Que TL (2007). A comparative Study on Bacterial Cultures of Urine Samples Obtained by Cleanvoid Technique Versus Urethral Catheterization. Acta Paediatr. 96: 432-6.

Long $E$ and Vince $J$ (2007). Evidence Behind the WHO Guidelines: Hospital Care for Children: What Are Appropriate Methods of Urine Collection in UTI? J Trop Pediatr. 53: 221-4.

Matutea AJ, Hakb E, Schurinkc CAM, McArthurd $A$, Alonsoe E, Paniaguae $M$, van Asbeck EA, Roskott EM, Froeling M, Rozenberg-Arskad M and Hoepelmancd I (2004). "Resistance of Uropathogens in Symptomatic Urinary Tract Infections in Leon, Nicaragua. Int $J$ Antimicrob Agents. 23: 506-9.

Okeke IN, Lamikanra A, and Edelman R (1999) Socioeconomic and Behavioral Factors Leading to Acquired Bacterial Resistance to Antibiotics in Developing Countries. Emerg Infect Dis. 5: 18-27.

Onipede $A O$, Oluyede $C O$, Aboderin AO, Zailani SB, Adedosu AB, Oyelese AO, Badmus TA, lkem I, Balogun $C O$ and Olafimihan KF (2004). A Survey of Hospital Acquired Infections in Obafemi Awolowo University Teaching Hospital, Ile-lfe. Afr J Clin Exp Microbiol. 5: 108-118. 
Rosenblatt JE (1983). Laboratory Tests Used to Guide Antimicrobial Therapy. Mayo Clin Proc. 58: 14-20.

Tal S, Guller V, Levi S, Bardenstein R, Berger D, Gurevich I and Gurevich A (2005). Profile and Prognosis of Febrile Elderly Patients with Bacteremic Urinary Tract Infection. J Infect. 50: 296-305.

Taiwo SS and Aderounmu AOA (2006). Catheter Associated Urinary Tract Infection: Aetiologic Agents and Antimicrobial Susceptibility Pattern in Ladoke Akintola University Teaching Hospital, Osogbo, Nigeria. Afr J Biomed Res. 9: 141 - 148.

Teshager L, Asrat D, Gebre-Selassie S and Tamiru S (2008). Catheterized and Noncatheterized Urinary Tract Infections Among
Patients Attended at Jimma University Teaching Hospital, Southwest, Ethiopia. Ethiop Med J. 46: 55-62.

Vandepitte J, Engbaek K, Piot P, Heuck CC and Rohner P (2003). Basic Laboratory Procedures in Clinical Bacteriology. WHO. $2^{\text {nd }}$ Edition. Pp: 3036

Willson $M$, Wilde $M$, Webb ML, Thompson D, Parker D, Harwood J, Callan L and Gray M (2009). Nursing Interventions to Reduce the Risk of Catheter-associated Urinary Tract Infection: Part 2: Staff Education, Monitoring, and Care Techniques. J Wound Ostomy Continence Nurs. 36: 137-54. 